\title{
From Insult to Injury: How Disputes Begin and Escalate among Adolescents and Young Adults in Medellin, Colombia
}

\author{
Luis F. Duque* and Nilton E. Montoya
}

\author{
PREVIVA, Facultad de Salud Publica, Universidad de Antioquia, Medellin, Colombia
}

\begin{abstract}
This article aims to contribute to the understanding of circumstances, causes of initiation, and process of escalation of physical disputes or fights resulting in physical injury. We analyzed data from a case-control study of perpetrators of violence between the ages of 15 to $24(n=373)$ in the city of Medellín, Colombia. The findings show that $89 \%$ of conflicts resulting in injury took place in public places and most often involved males (78\%). Six percent involved the consumption of alcohol, $20 \%$ reported having used illicit drugs before the initiation of the confrontation. Circa $50 \%$ of disputes began because of verbal aggression. Alcohol consumption was found to be associated with verbal aggression towards a friend or companion but not to other circumstances that start disputes. Drug use was not associated with the initiation of disputes. In $18.5 \%$ of the cases, a weapon was used while $5 \%$ of these disputes ended in a homicide. In none of the cases in which homicide was the outcome was there bystander intervention. In contrast, homicide did not result in the cases in which bystanders intervened.
\end{abstract}

Keywords: Youth violence, disputes, fights, conflicts, Colombia.

\section{INTRODUCTION}

Colombia is the fourth most populated country in the Americas, after the United States, Brazil and Mexico. The country has 44 million inhabitants and is located in the northeastern corner of South America. Medellin is the second largest city of Colombia with two and half million inhabitants. In Medellin-as well as in the entire country-the 1980s were characterized by an epidemic of violence that reached its peak in the year 1991 when there were 384 homicides reported for every 100,000 inhabitants (Duque 2007). After this period, Medellin experienced the largest decrease in reported homicides in the western hemisphere, eventually dipping to 25 homicides for every 100,000 inhabitants in 2008. In 2010, homicides began to increase once more, reaching 65 homicides per 100,000 inhabitants. Community violence in Colombia has been characterized by synergistic and intertwining forces that include: common delinquency, organized crime related to drug trafficking, and right- (paramilitaries) and leftwinged (guerrillas) armed conflict.

In Colombia, injuries are often the result of disputes (Cardona, Rodríguez and Hernández 2004; Hernández 2011; Hoz 2007 and Soriano 2003). Fifty six percent of 145,184 non-fatal violence-related injuries reported to the National Institute of Legal Medicine and Forensic Sciences of Colombia in 2010, were attributed to interpersonal conflicts (while $6 \%$ and $12 \%$ of the nonfatal injuries were due to economic and political

*Address correspondence to this author at the Facultad de Salud Publica, Universidad de Antioquia, Calle 62 \# 52-59, Of 213, Medellin, Colombia; Tel/Fax: +(57) (4) 210-6868; E-mails: Ifduque.ramirez@gmail.com, Ifduque@saludpublica.udea.edu.co conflicts, respectively). More than half (58\%) occurred in a public venue while $15 \%$ took place in a place of residence and another $7 \%$ in a commercial establishment (Hernández 2011). No information on the triggers for these incidents is reported in these publications.

Conflicts or disputes have also been cited as frequent causes of homicides (Fox and Zawitz 2007) and emergency room visits (Cheng et al. 2006) in the U.S. Given the importance of disputes as a cause of violent injuries, it is surprising that so little has been published on the triggers and circumstances surrounding these incidents. A literature search utilizing MEDLINE and PSYCHINFO with the search words "violence" and ("conflict" or "argument" or dispute") and ("circumstances" or "triggers") for the years 1985-2012 identified only three studies presenting data on the circumstances leading to the initiation and escalation of disputes associated with violent injury (Cheng et al., 2006; Hausman, Spivak and Prothrow-Stith 1989 and McMullen 2003). In these studies, verbal aggression was the main trigger for physical disputes.

The purpose of this analysis was to contribute to our understanding of the circumstances that trigger conflicts and the chain of events that follow leading to physical injury. A better understanding of this chain of events might identify opportunities for developing interventions to prevent violence.

\section{METHODS}

The data for this analysis come from a case control study conducted in Medellin from 2003 to 2004 to study the factors associated with perpetration of violence. 
Study participants were between the ages of 15 and 24 $(n=373)$ and were recruited in their communities from the poorest and most violent neighborhoods in Medellin. Participants were identified by snowballing and networking with community institutions, leaders, and groups.

Cases included individuals reporting involvement in four or more fights leading to physical injury over the last 12 months or identified by others because of frequent involvement in fights leading to injuries over the same period of time $(n=76)$; individuals identified as being involved or reporting involvement in four or more armed assaults or extortion of others for personal motives or after being asked to do so by a third party in the past 12 months $(n=63)$, and individuals identified by a band leader or self-identified as an active member of the Autodefensas Unidas de Colombia, a paramilitary organization, during the past two years and who had not been reintegrated socially to civil society $(n=72)$. No urban militiae associated with the guerrillas were found because at the time of data collection these had been displaced by high level paramilitary groups in the city.

The control group in the case control study included resilients, who are individuals exposed to two or more adverse situations (i.e., separated parents; having been abandoned by one or both parents; family unable to buy food on at least three consecutive days while growing up; having been a victim of forced displacement; having suffered physical or sexual abuse; or having lost a parent, sibling, or guardian due to violence), but showing a positive outcome beyond what would be expected in their community, such as

Table 1: Grouped Variables by Factorial Analysis

\begin{tabular}{|c|c|}
\hline Type of aggression & Description \\
\hline \multirow{6}{*}{ Verbal aggression } & An individual made fun of you, or made an ill intentioned joke on you \\
\hline & You made fun of or made an ill intentioned joke on an individual \\
\hline & An individual insulted or offended you \\
\hline & You insulted or offended an individual \\
\hline & An individual responded with insults \\
\hline & You insulted or responded with insults \\
\hline \multirow{2}{*}{ Hassling a friend or a companion } & An individual hassled your friend or your companion \\
\hline & You hassled either a friend or a companion of another person \\
\hline \multirow{4}{*}{ Demanding paying-off debts or fulfilling business } & An individual demanded you to pay off a debt you owed him/her \\
\hline & You demanded an debtor to pay you back his/her debt \\
\hline & $\begin{array}{l}\text { An individual demanded you to fulfill a previously mutually agreed business or } \\
\text { commitment. }\end{array}$ \\
\hline & $\begin{array}{l}\text { You demanded the fulfillment of a previously mutually agreed business or } \\
\text { commitment. }\end{array}$ \\
\hline \multirow{3}{*}{ Physical aggression without weapons } & A group attacked you or another person without a weapon \\
\hline & You were hit by an individual with his/her bare hands \\
\hline & You hit an individual with your bare hands \\
\hline \multirow{2}{*}{ Physical aggression with weapons } & An individual used a weapon \\
\hline & You used a weapon \\
\hline Others try to stop the fight & Bystanders tried to stop the fight and calm you down \\
\hline \multirow{2}{*}{ Bystanders come to help the respondent } & You were defended by others \\
\hline & Other people came in the other'(s) defense \\
\hline \multirow{2}{*}{ Trying to stop the fight } & Another person tried to stop the fight but was not allowed \\
\hline & You tried to stop the fight but were not allowed \\
\hline \multirow{2}{*}{ Walking away from the scene } & Other(s) walked away \\
\hline & You walked away \\
\hline Homicide & You killed an individual \\
\hline
\end{tabular}


being a class monitor or belonging to an institutional university young researchers group; having been officially recognized for academic or personal achievements in high school; being an employee in the middle management or general direction of a recognized company in the city; having their own legally recognized small business or micro-enterprise for at least two years or; being a formal leader in a religious, civil, sporting or youth-related community service organization $(n=59)$; and individuals identified by community leaders or directives of educational or youth institutions that reported none of the above violent behaviors and lived in the same residential areas as the cases.

Potential participants were contacted personally or by phone and informed of the purpose of the study and the confidentiality of the information collected. All participants were interviewed face-to-face with a standardized structured interview that included questions on demographics, family of origin, personal beliefs and attitudes, substance use, and involvement in violence. The interview also included questions concerning the frequency of involvement in disputes, or fights leading to physical lesion over their lifespan and their occurrence in the past year as well as questions on the day of the week, time of day of these incidents. The instrument also explored 25 potential situations to establish triggers, escalation, and resolution for the last incident in which the participant was involved. This tool was designed based on a consultation with experts in the subject matter. Situations mentioned by respondents but not on this list were captured verbatim and subsequently coded.

Interviews were undertaken at a place, day, and time agreed upon by the leaders of the paramilitary group, gang, or entity that had facilitated contact with the participant. Interviewers (four women and three men) were sociologists and anthropologists who received a week-long training. Each interview lasted between 60 and 90 minutes.

A regression tree method (Breiman, Friedman, Stone and Olshen 1984) was used to analyze the initiation, escalation and resolution of the physical fights with physical lesion. In order to increase the capacity to explain the course of physical disputes, variables were grouped by way of a factorial analysis with the use of the Varimax Rotation and a KMO of 0.76 before being included into the regression tree (Table 1).

Once variables were grouped, a step-by-step tree model was drawn, starting with a branch for each event's outcome, along with its partial probability (in parenthesis) and total probability. Each one of these branches is called a first generation branch. In each first generation branch, a knot is built from which second generation branches are generated based on the outcomes of the second event or step. This process is subsequently repeated until the final event is reached, once all other options to analyze the event have been exhausted.

We calculated the confidence interval $(95 \% \mathrm{Cl})$ of each event's outcome and if it overlapped with the $95 \%$ $\mathrm{Cl}$ of an event's outcome from another tree model, where no significant difference between these two models was otherwise inferred.

\section{RESULTS}

\section{Person, Time and Place of the Assaults}

Based on incidents occurring in the past 12 months, Friday and Saturday were the days in which disputes were most frequently reported $(23 \%$ and $21 \%$

Table 2: Study Groups Characteristics. Percentage Distribution

\begin{tabular}{|c|c|c|c|c|}
\hline \multirow{2}{*}{ Sex } & RESILIENTS & COMMUNITY CONTROLS & CASES \\
\hline \hline \multirow{3}{*}{ Age } & Masculine & 60.8 & 66.7 & 88.7 \\
\cline { 2 - 5 } & Feminine & 39.2 & 33.3 & 11.3 \\
\cline { 2 - 5 } & $15-17$ years & 43.1 & 36.3 & 51.3 \\
\hline \multirow{3}{*}{ Education } & $18-24$ years & 56.9 & 63.7 & 48.7 \\
\cline { 2 - 5 } & None & 0.0 & 1.0 & 10.4 \\
& Elementary & 0.0 & 15.7 & 25.2 \\
\cline { 2 - 5 } & High School & 43.1 & 52.0 & 57.4 \\
\hline
\end{tabular}


respectively), followed by Wednesdays (15\%). The highest proportion of disputes (41\%) took place between 2:00 and 6:00 in the afternoon while 35\% occurred in the nighttime hours between 7:00 p.m. and midnight. The smallest proportion (23\%) reportedly transpired in the morning hours between 1 a.m. and midday. The vast majority (89\%) of disputes occurred in public places such as streets, parks, vacant lots and sport fields, while $11.0 \%$ took place in the home and $7.5 \%$ occurred in places where liquor is dispensed.

Of those who reported participating in disputes, two thirds reported not having consumed alcohol or drugs before the incident (Table 3). Fifteen percent reported having consumed alcohol and $28 \%$ reported having consumed drugs before the incident. Eight percent having consumed both.

Table 3: Percentage and 95\% Confidence Interval of Youths 15 to 24 Having Consumed Alcohol or Drugs Before a Fight. Medellin, Colombia

\begin{tabular}{|c|c|}
\hline Type of consume & Percent \\
\hline \hline Only alcohol & 6.6 \\
& $(4.2-9.0)$ \\
\hline Only drugs & 19.7 \\
& $(12.6-26.8)$ \\
\hline Both alcohol and drugs & 8.2 \\
Neither & $(5.2-11.2)$ \\
\hline & $(42.0-89.6$ \\
\hline
\end{tabular}

$\mathrm{N}=198$ fights.

Alcohol consumption is associated with the initiation of physical aggression but not with other behaviors such as verbal aggression. The use of illegal drugs was not associated with the initiation of the confrontation. See Table 4.

\section{ESCALATION OF CONFLICTS}

Generally, respondents reported disputes beginning with verbal aggression and progressing to a physical fight. However, in $10 \%$ of the cases physical aggression was the starting point. A weapon was used in $18 \%$ of the incidents. Insults or derogatory comments were the trigger for disputes in $53 \%$ of the incidents, followed by someone harassing a person's friend or companion (27\%). In almost half $(45 \%)$ of incidents bystanders involved themselves to stop the fight and $15 \%$ of bystanders intervened to defend one of the participants from either side of the fight.

Overall, homicide was the final outcome in $5 \%$ of the incidents. Homicide was the final result in $20 \%$ of the cases in which a weapon was used. Forty-six percent of disputes that ended in homicide started with verbal aggression while $33 \%$ began with physical aggression.

When bystanders intervened to diffuse the situation or separate those involved before the confrontation became physical in nature, this usually led to one of the participants abdicating. On the other hand, there was no bystander intervention in any of the cases of disputes that ended in homicide.

Table 5 shows what event triggered the start of a fight, its escalation and its general final outcome. Being verbally aggressed was the most common physical fight trigger (49\%) and verbal aggression against a companion or friend was the second physical fight trigger (30\%). A fight's escalation was mainly related to physical aggression (51\%) and verbal aggression (24\%). Fights stopped mainly once the participant or bystanders walked away (68\%) or when fighters were calmed down by bystanders (30\%).

Five patterns of disputes were identified out of which four were found to be statistically significant, and are presented in Figures 1, 2, 3 and 4. Each tree branch displays the partial (in parenthesis) and total probabilities along with the subsequent outcomes.

The most frequent chain of events begins with verbal aggression toward another or being the recipient of verbal aggression. In $69 \%$ of the cases, physical aggression followed. The incident ended in a homicide in $5 \%$ of the cases. In another $35 \%$ of the cases the individuals involved in the confrontation left the premises, and a bystander intervened to end the fight in $44 \%$ of the incidents. Sixty-five percent of all disputes in this study followed this pattern (see Figure $1)$.

Figure 2, presents the second most frequent sequence of events, characteristic of $20 \%$ of the incidents studied. These, began with physical aggression, and escalated to use of a weapon in $27 \%$ of cases of which a third ended in a homicide. It was resolved by one of the two parties leaving the area $53 \%$ of the time or killing one of those involved in $10 \%$ of the incidents.

The third pattern identified in this analysis initiated with a demand for money (or other business-related reclamation), and was followed, with physical aggression in all cases. A weapon was employed half the time but none of the incidents in this pattern ended 
Table 4: Proportion of Aggressors of Disputes by Psychoactive Consumption. Medellín, Colombia

\begin{tabular}{|c|c|c|c|c|c|}
\hline & & Alcohol & Drugs & Both & Neither \\
\hline $\begin{array}{l}\text { Someone made fun of you, or made a harsh } \\
\text { joke }\end{array}$ & $\mathrm{P}$ & 7,4 & 11,8 & 0,0 & 10,2 \\
\hline $\begin{array}{l}\text { You made fun of someone, or made a harsh } \\
\text { joke }\end{array}$ & $\mathrm{P}$ & 0,0 & 2,0 & 0,0 & 2,4 \\
\hline \multirow[b]{2}{*}{ Someone annoyed your friend or companion } & $P$ & 29,6 & 19,6 & 33,3 & 8,3 \\
\hline & $\mathrm{Cl}$ & $(13,8-50,2) n=27$ & $(9,8-33,1) n=51$ & $\begin{array}{c}(11,8-61,6) \\
n=15\end{array}$ & $\begin{array}{c}(4,9-12,9) \\
n=205\end{array}$ \\
\hline $\begin{array}{l}\text { You annoyed someone else's friend or } \\
\text { companion }\end{array}$ & $P$ & 0,0 & 5,9 & 0,0 & 2,0 \\
\hline Someone insulted or offended you & $\mathrm{Cl}$ & $\begin{array}{c}(11,1-46,3) \\
n=27\end{array}$ & $\begin{array}{c}(11,3-35,3) \\
\quad n=51\end{array}$ & $\begin{array}{c}(7,8-55,1) \\
n=15\end{array}$ & $\begin{array}{c}(14,3-25,6) \\
n=205\end{array}$ \\
\hline \multirow[b]{2}{*}{ You insulted or offended someone } & $P$ & 14,8 & 15,7 & 6,7 & 13,7 \\
\hline & $\mathrm{Cl}$ & $\begin{array}{c}(4,2-33,7) \\
n=27\end{array}$ & $\begin{array}{c}(7,0-28,6) \\
n=51\end{array}$ & $\begin{array}{c}(0,2-31,9) \\
n=15\end{array}$ & $\begin{array}{c}(9,3-19,1) \\
n=205\end{array}$ \\
\hline \multirow[b]{2}{*}{$\begin{array}{l}\text { Someone demanded that you pay them back } \\
\text { some money you owed them }\end{array}$} & $P$ & 0,0 & 0,0 & 0,0 & 1,0 \\
\hline & $\mathrm{Cl}$ & NA & NA & NA & $\begin{array}{c}(0,1-3,5) \\
n=205\end{array}$ \\
\hline \multirow[b]{2}{*}{$\begin{array}{l}\text { You demanded that someone pays you back } \\
\text { some money they owed you }\end{array}$} & $P$ & 0,0 & 3,9 & 0,0 & 1,0 \\
\hline & $\mathrm{Cl}$ & NA & $\begin{array}{c}(0,5-13,5) \\
n=51\end{array}$ & NA & $\begin{array}{c}(0,1-3,5) \\
n=205\end{array}$ \\
\hline $\begin{array}{c}\text { You claimed or demanded to another person } \\
\text { that they fulfill a business or a mutual } \\
\text { agreement }\end{array}$ & $\mathrm{Cl}$ & $\begin{array}{c}(2,4-29,2) \\
n=27\end{array}$ & $\begin{array}{c}(7,0-28,6) \\
n=51\end{array}$ & $\begin{array}{c}(1,7-40,5) \\
n=15\end{array}$ & $\begin{array}{c}(16,5-28,2) \\
n=205\end{array}$ \\
\hline \multirow[b]{2}{*}{ Someone hit you } & $\mathrm{P}$ & 51,9 & 35,3 & 33,3 & 41,0 \\
\hline & $\mathrm{Cl}$ & $\begin{array}{c}(31,9-71,3) \\
n=27\end{array}$ & $\begin{array}{c}(22,4-49,9) \\
n=51\end{array}$ & $\begin{array}{c}(11,8-61,6) \\
n=15\end{array}$ & $\begin{array}{c}(34,2-48,0) \\
n=205\end{array}$ \\
\hline \multirow[b]{2}{*}{ You hit someone } & $P$ & 74,1 & 64,7 & 66,7 & 45,9 \\
\hline & $\mathrm{Cl}$ & $\begin{array}{c}(53,7-88,9) \\
n=27\end{array}$ & $\begin{array}{c}(50,1-77,6) \\
n=51\end{array}$ & $\begin{array}{c}(38,4-88,2) \\
n=15\end{array}$ & $\begin{array}{c}(38,9-52,9) \\
n=205\end{array}$ \\
\hline \multirow[b]{2}{*}{ Another person pulled out a gun and use it } & $\mathrm{P}$ & 3,7 & 15,7 & 6,7 & 4,4 \\
\hline & $\mathrm{Cl}$ & $\begin{array}{c}(0,1-19,0) \\
n=27\end{array}$ & $\begin{array}{c}(7,0-28,6) \\
n=51\end{array}$ & $\begin{array}{c}(0,2-31,9) \\
n=15\end{array}$ & $\begin{array}{c}(2,0-8,2) \\
n=205\end{array}$ \\
\hline \multirow{3}{*}{ You pulled out a gun and use it } & $\mathrm{P}$ & 3,7 & 23,5 & 6,7 & 5,4 \\
\hline & $\mathrm{Cl}$ & $\begin{array}{c}(0,1-19,0) \\
n=27\end{array}$ & $\begin{array}{c}(12,8-37,5) \\
n=51\end{array}$ & $\begin{array}{c}(0,2-31,9) \\
n=15\end{array}$ & $\begin{array}{c}(2,7-9,4) \\
n=205\end{array}$ \\
\hline & $\mathrm{Cl}$ & NA & $\begin{array}{c}(0,0-10,4) \\
n=51\end{array}$ & NA & $\begin{array}{c}(0,5-4,9) \\
n=205\end{array}$ \\
\hline
\end{tabular}


Table 5: Percentage of Behaviors that Triggered a Physical Fight with Injury, its Escalation and its Ending. Medellin, Colombia

\begin{tabular}{|c|c|c|c|c|c|}
\hline Start & $\%$ & Escalation & $\%$ & Ending & $\%$ \\
\hline $\begin{array}{l}\text { An individual insulted or offended } \\
\text { you }\end{array}$ & 26.3 & You hit an individual & 29.2 & You walked away & 36.9 \\
\hline $\begin{array}{c}\text { An individual made fun of you or } \\
\text { made an ill intentioned joke on } \\
\text { you }\end{array}$ & 20.3 & You were hit by an individual & 22.0 & The other(s) walked away & 31.3 \\
\hline You insulted an individual & 3.1 & Subtotal Physical aggression & 51.2 & $\begin{array}{c}\text { Bystanders calmed you down or } \\
\text { broke the fight }\end{array}$ & 29.6 \\
\hline $\begin{array}{c}\text { Subtotal Verbal aggression } \\
\text { against interviewee }\end{array}$ & 49.7 & $\begin{array}{c}\text { An individual insulted or offended } \\
\text { you }\end{array}$ & 12.0 & - & - \\
\hline $\begin{array}{l}\text { An individual insulted or offended } \\
\text { your friend or companion }\end{array}$ & 22.6 & $\begin{array}{l}\text { You insulted or responded with } \\
\text { insults }\end{array}$ & 10.0 & - & - \\
\hline $\begin{array}{l}\text { You offended another person's } \\
\text { friend or companion }\end{array}$ & 4.5 & $\begin{array}{l}\text { An individual responded with } \\
\text { insults }\end{array}$ & 0.9 & - & - \\
\hline $\begin{array}{l}\text { You made fun of another person } \\
\text { or made an ill intentioned joke }\end{array}$ & 3.0 & $\begin{array}{c}\text { An individual made fun of you. or } \\
\text { made an ill intentioned joke on } \\
\text { you }\end{array}$ & 0.6 & - & - \\
\hline $\begin{array}{c}\text { Subtotal Verbal aggression } \\
\text { against a companion or friend }\end{array}$ & 30.1 & $\begin{array}{l}\text { You insulted either a friend or a } \\
\text { companion of another person }\end{array}$ & 0.2 & You killed the other person & 2.2 \\
\hline $\begin{array}{l}\text { You demanded the payoff of a } \\
\text { debt }\end{array}$ & 3.0 & $\begin{array}{c}\text { You made fun of another person. } \\
\text { or made an ill intentioned joke } \\
\text { about him/her }\end{array}$ & 0.6 & - & - \\
\hline $\begin{array}{l}\text { You demanded the fulfillment of a } \\
\text { previously mutually agreed } \\
\text { business or commitment. }\end{array}$ & 2.3 & Subtotal Verbal aggression & 24.3 & - & - \\
\hline $\begin{array}{l}\text { An individual demanded you to } \\
\text { fulfill a previously mutually agreed } \\
\text { business or commitment. }\end{array}$ & 1.5 & $\begin{array}{l}\text { An individual tried to stop the fight } \\
\text { but was not allowed }\end{array}$ & 5.7 & - & - \\
\hline $\begin{array}{l}\text { An individual demanded you to } \\
\text { pay off a debt you owed him/her }\end{array}$ & 0.8 & You used a weapon & 4.4 & - & - \\
\hline $\begin{array}{l}\text { Subtotal An individual } \\
\text { demanded you to pay off a debt } \\
\text { you owed him/her, or you } \\
\text { demanded it to him/her }\end{array}$ & 7.6 & An individual used a weapon & 3.3 & - & - \\
\hline An individual hit you & 7.5 & $\begin{array}{l}\text { Bystanders tried to stop the fight } \\
\text { and calm you down }\end{array}$ & 3.1 & - & - \\
\hline $\begin{array}{l}\text { A group attacked the other } \\
\text { group(s) without weapons }\end{array}$ & 1.5 & $\begin{array}{c}\text { Other people came in your } \\
\text { defense }\end{array}$ & 3.1 & - & - \\
\hline You hit an individual & 1.5 & $\begin{array}{l}\text { One group attacked the other } \\
\text { group(s) }\end{array}$ & 1.9 & - & - \\
\hline You used a weapon & 1.5 & $\begin{array}{l}\text { You tried to stop the fight but were } \\
\text { not allowed }\end{array}$ & 1.2 & - & - \\
\hline An individual used a weapon & 0.8 & $\begin{array}{c}\text { Other people came in the other'(s) } \\
\text { defense }\end{array}$ & 0.9 & - & - \\
\hline- & - & $\begin{array}{l}\text { You demanded the fulfillment of a } \\
\text { previously mutually agreed } \\
\text { business or commitment. }\end{array}$ & 0.6 & - & - \\
\hline \multirow[t]{3}{*}{-} & - & & & & \\
\hline & & $\begin{array}{l}\text { An individual demanded you to } \\
\text { pay off a debt you owed him/her }\end{array}$ & 0.2 & - & - \\
\hline & & $\begin{array}{l}\text { You tried to stop the fight but were } \\
\text { not allowed }\end{array}$ & 0.2 & - & \\
\hline TOTAL N = 198 & $100.2 \%$ & TOTAL N = 198 & $100.1 \%$ & TOTAL N = 198 & $100.0 \%$ \\
\hline
\end{tabular}




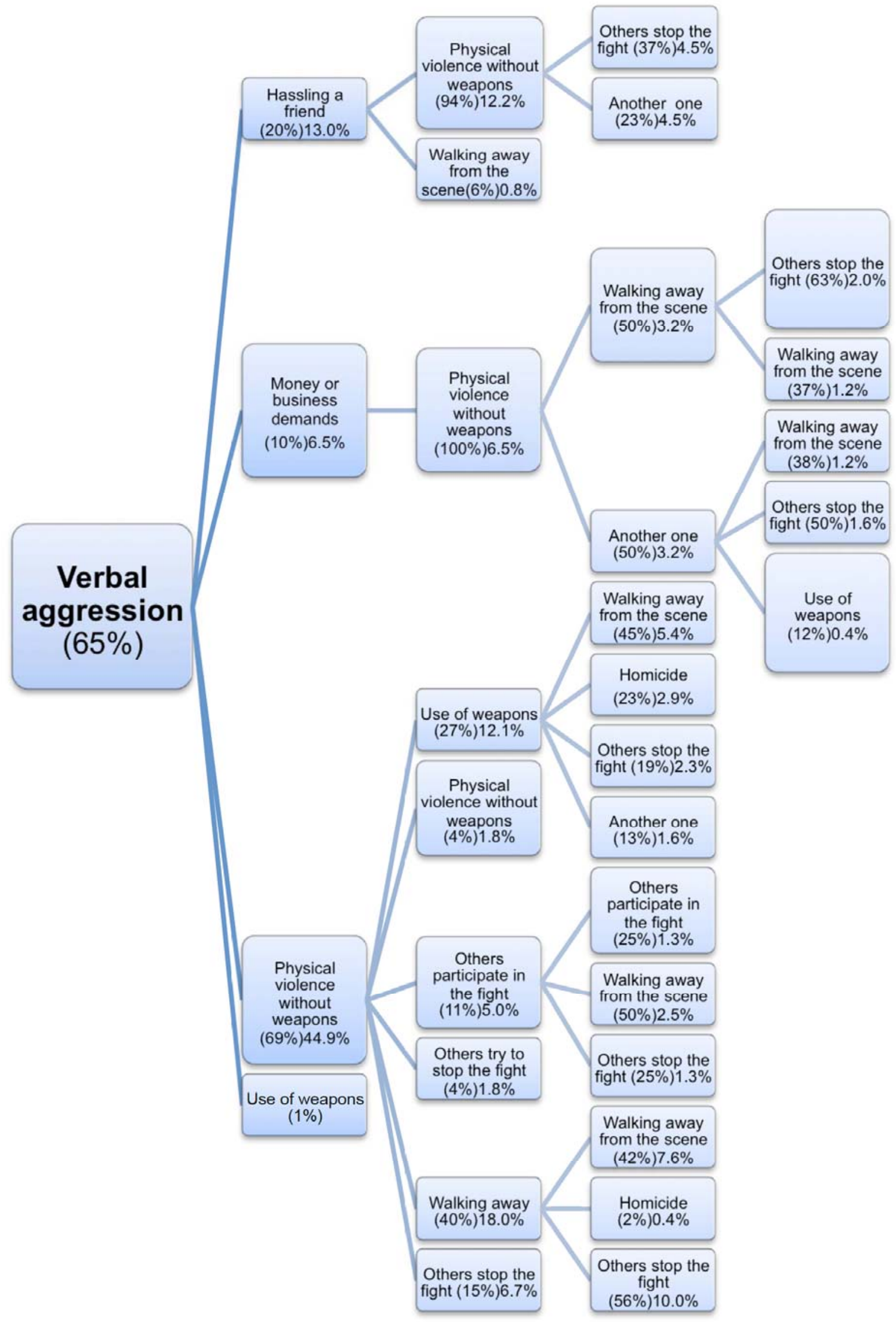

Figure 1: First most frequent generation sequence and process of fights development. Medellin, Colombia. 


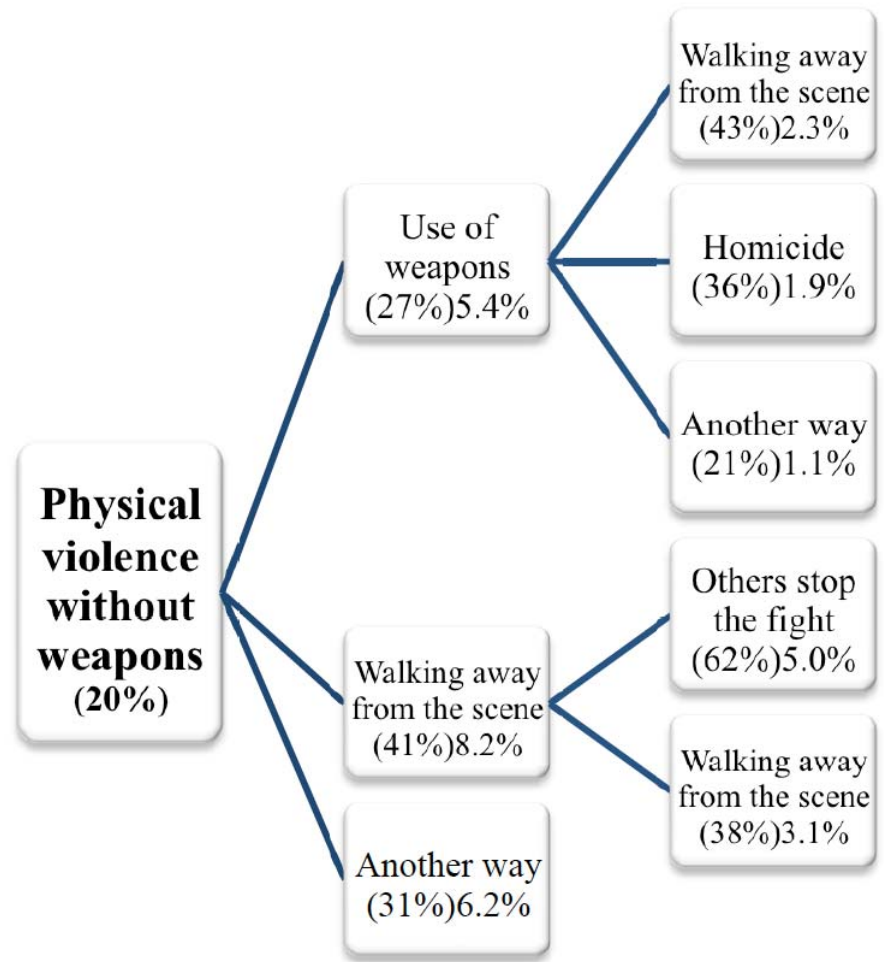

Figure 2: Second most frequent generation sequence and process of fights development. Medellin, Colombia.

with a homicide. This pattern represented $6 \%$ of the disputes in the study (Figure 3 ).

The fourth pattern of events initiated with harassment of a companion or friend of the individual and was followed with physical aggression in all incidents. In half of these incidents one of the opponents either left the premises or a bystander intervened to stop the altercation. This pattern corresponded to $6 \%$ of the study cases (Figure 4).

\section{DISCUSSION}

The purpose of this analysis was to utilize data collected for a case-control study on perpetrators of violence in Medellin to examine circumstances that trigger disputes leading to injury and the chain of disputes events and circumstances. The findings show that verbal aggression was the most frequent trigger of events and that incidents occurred most often in the afternoon hours and out in public spaces. Seven and $20 \%$ involved the consumption of alcohol and illicit drugs respectively, and 8 involved both before initiation of the confrontation. In none of the cases in which the physical dispute ended in homicide did a third party intervene while there were no homicides in all incidents in which bystanders intervened.

Before discussing the potential implications of these findings, various limitations of the study should be acknowledged. A first limitation is the study design. Case-control studies do not generally select participants at random from the general population or even from the universe of all potential cases or controls. In this study, participants from poor neighborhoods meeting certain criteria were actively

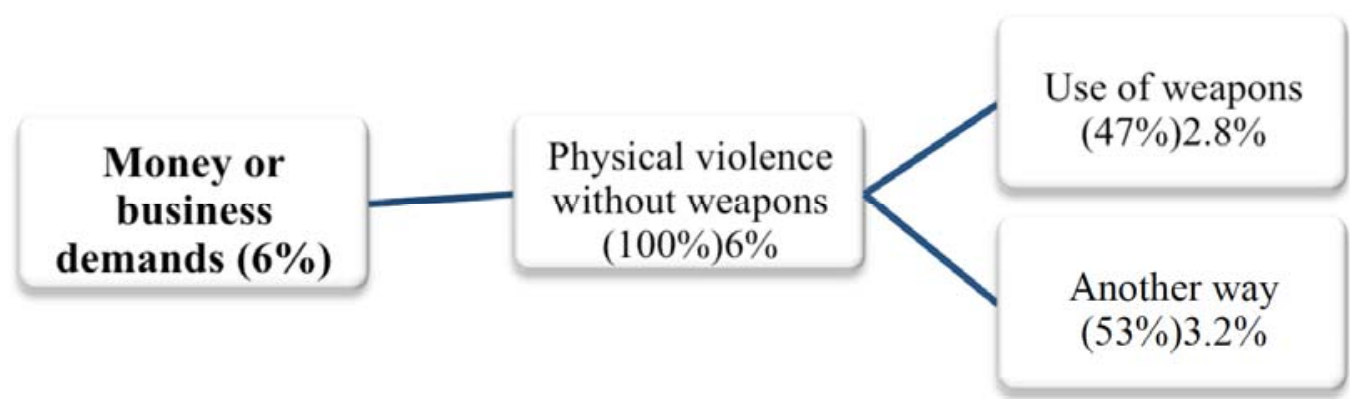

Figure 3: Third most frequent generation sequence and process of fights. Medellin, Colombia. 


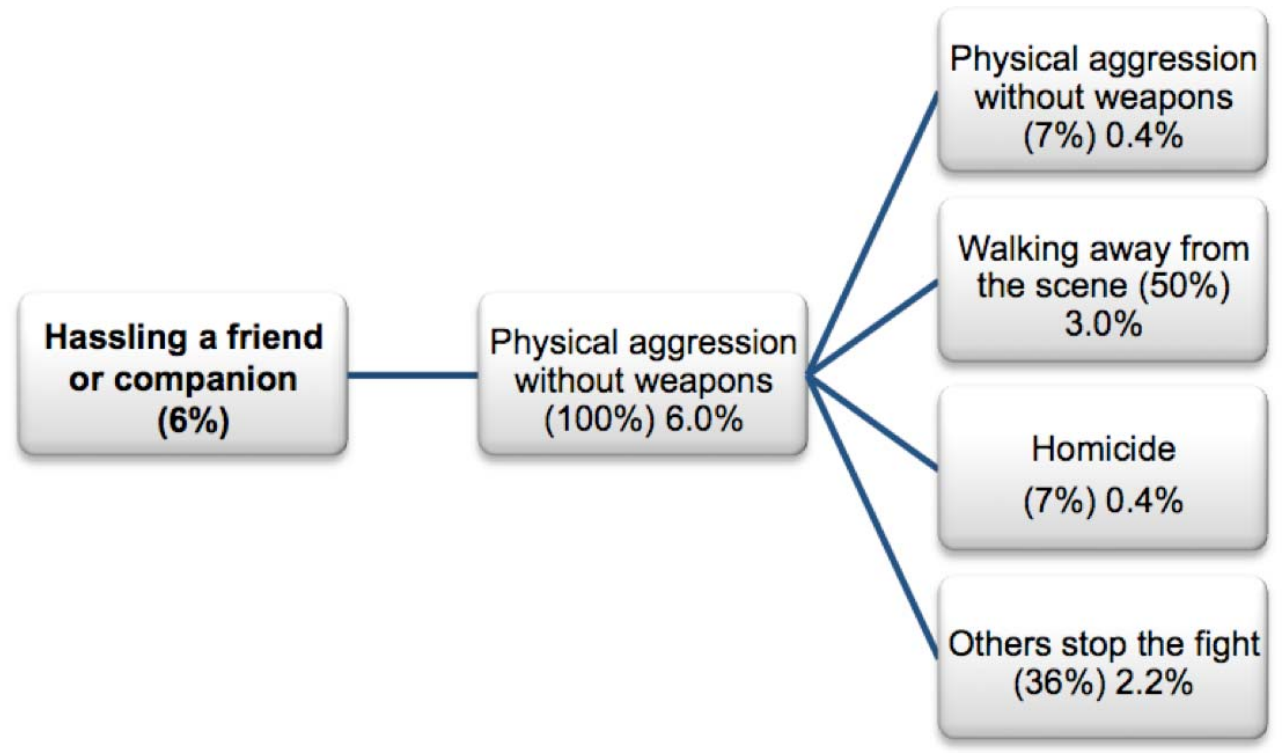

Figure 4: Fourth most frequent generation sequence and process of fight development. Medellin, Colombia.

recruited, and thus they are not statistically representative of the general population of 15 to 24 year-olds. In addition, information on incidents was based only on the participants' recall of the last incident he/she was involved in, no matter how long ago this may have occurred, with no direct observations or triangulation with other participants or observers of the chain of events. Therefore the description of incidents may be subject to social desirability or recall biases.

Despite these limitations, some of the findings are consistent with other studies. For example, the findings in this study concerning the places where disputes took place are similar to those reported by the Colombian Institute of Legal Medicine and Forensic Sciences (Cardona et al. 2004; Hernández 2011; Hoz 2007 and Soriano 2003), though the disputes in the current study were limited to an urban area while the data from this Institute includes both urban and rural areas. The main trigger for physical disputes (verbal aggression) is also the same in our study as in two other studies (Cheng et al. 2006; Hausman et al. 1989) identified by our literature search.

Other findings, however, contradict what has been previously observed. In this study, fifteen per cent of participants reported consuming alcohol previous to the incident, while the Colombian Institute of Forensic Medicine reported double that rate nationally. However, estimates from the Colombian Institute of Legal Medicine and Forensic Sciences (ICMLCF) are based on cases seen at ICMLCF, which may be more severe that those analyzed in this study. Reviews of research in the U.S. have reported similar (Kodjo, Auinger and
Ryan 2004) or higher rates than ours of alcohol consumption immediately before violent incidents (Reiss and Roth 2003). Given the limitations of the study, the reasons for this discrepancy are not clear. An underestimate of the real prevalence of drinking among this group due to social desirability does not seem to be the case given that a high proportion (28\%) admitted to consuming illicit drugs. Perhaps over time, illicit drug use has partially replaced alcohol consumption among this population group. In Colombia an increase of $38 \%$ in cocaine consumption has been reported in the student population between 2004 and 2011 (1.6 and 2.2, respectively), in the last 12 months and a slight decrease (9\%) in alcohol consumption (49.0 and 44.4 per 100) in the last 12 months (Ministerio de Salud y Protección Social and Ministerio de Educación y Ministerio de Justicia 2009). Even though there are reports suggesting that alcohol and marijuana consumption may lead teens to engage in physical fights, (while cocaine use appears to have no relationship) (Markowitz 2001), the role of alcohol in violent incidents needs to be more rigorously established before recommending public policies such as increased taxes or curfews for bars to prevent violence. To rigorously establish this relationship, data should be collected from multiple sources on a more representative sample of incidents. In addition, data on the proportion of people not involved in violent incidents at the same time, day of the week, and place while drinking would also be needed for comparison.

Among this sample, bystander intervention appeared to influence the outcomes. In none of the 
cases in which the physical dispute ended in a homicide did a third party intervene to assuage the situation and/or separate the participants. On the contrary, in all cases in which bystanders intervened, the confrontation did not turn fatal. Previous studies on the circumstances of physical disputes did not examine the influence of bystanders and so this finding should be explored further. If it is replicated, it justifies more extensive development and evaluation of interventions to mobilize bystanders to intervene safely and effectively when there are aggressive conflicts. This idea makes sense given that disputes commonly take place in public areas during hours when bystanders are likely to be present. Participation of bystanders could also be modulated by their perception of risk to themselves. Non-participation of bystanders could reflect a perception that the situation is more likely to end with a lethal outcome and this perception of risk could preclude them from participating. However, there is evidence that bystanders intervene precisely when the dispute is more severe (Parks et al. 2013).

Youth and adolescents in violent communities may sometimes consider their participation in physical assaults to be advantageous, bringing satisfactory feelings of revenge, increasing respect, popularity and social power among peers, and potentially preventing more serious confrontations in the future (Johnson et al. 2004). These findings suggest that current violent prevention programs with messages asking that youngsters walk away from conflict may need to be tailored. However, there are other potential avenues for the prevention of injuries caused by physical disputes. Early and persistent childhood aggression is the best predictor of perpetration of violence as an adolescent and adult, and there are efficacious interventions to modify the course of childhood aggression (Connor 2002; Farrington and Welsh 2007; Wasserman and Millar 1998; Welsh and Farrington 2007).

\section{What is Already Known?}

- Injuries are often the result of disputes

- Injuries are more common in developing countries than in developed ones

- $\quad$ There is scarcity of scientific evidence especially in developing countries dealing with triggers and actions following them across fights initiation, escalation and resolution

- $\quad$ There is no consensus about place where fights mostly occur

\section{What this Study Adds?}

- $\quad$ Scientific evidence on disputes dynamics from a violent and developing country

- Most disputes and fights take place at open places

- The more common fight triggers were verbal aggression (87\%), including insults, to offend a friend or companion, claims for debts or business, second place is for physical aggression without a weapon (9\%), followed by physical aggression with a weapon (2\%).

- $\quad$ Five patterns of disputes were identified out of which four were found to be statistically significant.

- Homicide was the final outcome in $5 \%$ of the incidents. Homicide was the final result in $20 \%$ of the cases in which a weapon was used. Forty-six percent of disputes that ended in homicide started with verbal aggression while $33 \%$ began with physical aggression.

- Bystander intervention appeared to influence the outcomes. In none of the cases in which the physical dispute ended in homicide did a third party intervene to assuage the situation and/or separate the participants. On the contrary, in all cases in which this intervention took place, the confrontation did not turn fatal.

- $\quad$ Of those who reported participating in disputes, two thirds reported not having consumed alcohol or drugs before the incident. It seems that among this sample alcohol and drugs do not play a major influence to disputes leading to injury, except where alcohol consumption is associated with verbal aggression towards a friend or companion.

\section{Policy Implications}

These findings suggest that there is potential impact regarding bystander interventions, and less potential for public policies that restrict access to alcohol.

\section{FUNDING}

This study was sponsored by the Colombian Institute for the Development of Science and Technology (Instituto Colombiano para el Desarrollo de la Ciencia y la Tecnología -COLCIENCIAS.) Contract 
RC 511 of 2002 Colciencias - Universidad de

Antioquia. We thanks to the sustainability strategy CODI, Universidad de Antioquia, 2013-2014.

\section{ACKNOWLEDGEMENTS}

We thank very much Dr. Joanne Klevens for her invaluable cooperation suggesting this article writing, and hot her technical support during its discussion. Dr. Alexandra Restrepo helping in bibliographic presentation is highly appreciated. We thank Marcela Correa for her assistance in coordinating data collection and management and Maria Clara Miranda for her assistance in bibliographic search.

\section{COMPETING INTERESTS}

Authors declare not having conflict of interest.

\section{REFERENCES}

Breiman, Leo, Jerome Friedman, Charles Charles and RA Olshen. 1984. Classification and Regression Trees. Pacific Grove, Belmont, CA: Wadsworth \& Brooks/Cole Advanced Books \& Software.

Cardona, Juan Ignacio, Andres Rodríguez and Wilson Hernández. 2004. El fenómeno de las riñas en la perspectiva ética. Forensis 5(1), 48-65.

Cheng Tina L, Sara Johnson, Joseph L Wright Joseph, Amari Pearson-Fiel, Ruth Brenner, Donal Schwarz Donald and Peter C. Scheidt Peter. 2006. Assault-injured Adolescents Presenting to the Emergency Department: Causes and Circumstances. Academic Emergency Medicine 13, 610-616. http://dx.doi.org/10.1111/j.1553-2712.2006.tb01019.x

Connor, Danel F. 2002. Aggression and antisocial behavior in children and adolescents. Research and Treatment. New York, NY.: The Guilford Press.

Duque, Luis Fernando. 2007. La violencia en el Valle de Aburrá. Caminos para la superación. Medellín: Cátedra Litográfica.

Farrington, David P and Brandon C Welsh. 2007. Saving Children from a Life of Crime. Early Risk Factors and Effective Interventions. New York, NY: Oxford University Press.

Fox, A James and Marianne W Zawitz. 2007. Homicide trends in the United States: Bureau of Justice Statistics.
Hausman, AJ, HR Spivak and D Prothrow-Stith. 1989. Adolescent interpersonal assault injury admissions in an urban municipal hospital. Pediatric emergency care 5, 275-280. http://dx.doi.org/10.1097/00006565-198912000-00022

Hernández, Wilson. 2011. Lesiones interpersonales. Colombia 2010 Forensis 12, 1(1), 58-90.

Hoz, Germán. 2007. Lesiones interpersonales. Relación entre factores socioambientales y genéticos que intervienen en el desarrollo de la violencia interpersonal. Forensis 8(1), 151 . 220

Johnson, SB, JLWright, CB Pearson-Fields and TL Cheng. 2004. Urban youths' perspectives on violence and the necessity of fighting. Injury Prevention 10, 187-291. doi: htpp://dx.doi.org/10.1136/ip.2004.005793.

Kodjo, Cheryk M, Peggy Auinger and Sheryl A Ryan. 200). Prevalence of factors associated with adolescent physical fighting while under the influence of alcohol or drugs. Journal of Adolescents Health 35(4), 346.e311-346.

Markowitz, Sara. The Role of Alcohol and Drug Consumption in Determining Physical Fights and Weapon Carrying by Teenagers. Eastern Economic Journal 2001(27), 409-432.

McMullen, Patricia. 200). The process of conflict and conflict resolution among older adolescents hospitalized at a trauma center as a consequence of violent incidents. Dissertation Abstracts International 63(12B).

Ministerio de Salud y Protección Social, Ministerio de Educación y Ministerio de Justicia. 2009. Estudio Nacional de Consumo de Sustancias Psicoactivas en población escolar de Colombia; Bogotá: Editorial Guadalupe.

Parks, MJ, DW Osgood, RB Felson, S Wells and K Graham. 201). Third Party Involvement in Barroom Conflicts. Aggressive Behavior 39(3), 1-12. http://dx.doi.org/10.1002/ab.21475

Reiss, Albert $\mathrm{J}$ and Roth Jeffrey. 2003. Understanding and Preventing Violence (Vol. 1). Washington, DC: National Academy Press.

Soriano, Marta. 2003. Lesiones interpersonales. Forensis 4(1), 4864.

Wasserman, Gail A and Laurie S Millar. 1998. The prevention of serious and violent juvenile offenders Serious \& Violent Juvenile Offenders. Risk Factors and Successful Interventions (pp. 197). Thousand Oaks, CA: Sage.

Welsh, Brandon and David Farrington. 2007. Preventing Crime. What Works for Children, Offenders, Victims and Places. New York, NY: Springer. http://dx.doi.org/10.1007/978-0-387-69169-5

\section{DOI: http://dx.doi.org/10.6000/1929-4409.2013.02.17}

(c) 2013 Duque and Montoya; Licensee Lifescience Global.

This is an open access article licensed under the terms of the Creative Commons Attribution Non-Commercial License (http://creativecommons.org/licenses/by-nc/3.0/) which permits unrestricted, non-commercial use, distribution and reproduction in any medium, provided the work is properly cited. 